\title{
Saint Louis as a New David and Paris as a New Jerusalem in Medieval French Hagiographic Literature
}

Jerzy Pysiak

Introduction: The French Royal Ideology and Its Byzantine Background

From the time of the royal anointing of Pepin the Short ( $75^{1}$ and 754 ), intentionally fashioned after (or interpreted as) the biblical anointing of the prophets and kings of Israel, David becomes an ideal model for the kings of the Franks. According to Earlier Annals of Metz Charlemagne was anointed thrice: as a child and heir presumptive with his father, Pepin the Short, and younger brother Carloman in 754; after Pepin's death in 768 as one of the two kings of Franks; finally after Carloman's retirement to the monastery, when he became the one and only king of the entire Frankish Kingdom in $771 .^{1}$ The Annalist does not compare Charlemagne directly to David, but the parallel seems to be manifest: David was also administered with triple anointment: the first one while still a boy, during Saul's reign; the second as a king of Judah, and eventually as a king of Israel, uniting all the tribes of Israel. ${ }^{2}$ While in their literary correspondence the intellectuals from the Carolingian court - indulging in a kind of intellectual game - used to assign each other literary surnames borrowed from ancient Roman poets, Charlemagne was called by the name of David. Yet, for Alcuin of York, Charlemagne's close advisor and one of the founders of the Carolingian royal ideology (he himself used to be called Flaccus), David is not indeed the king's surname. In effect, Charlemagne is a modern-day David and this similarity between the Carolingian emperor and King David is justified by the analogy of the task assigned to both monarchs: like the king of Israel, Charlemagne was supposed to be responsible for the purity of the Church and of the divine worship in order to ensure the salvation of his subjects. Incidentally, for similar reasons, Charlemagne was also considered a new Josiah, the pious king of Judah who restored both the Temple and the Law to

1 Annales Mettenses priores, pp. 45-46, 56 and $57 \mathrm{ff}$.

2 1 Samuel 16:13; 2 Samuel 2:4 and 5:3. 
their former glory. In addition, it was thought that the people of Franks had replaced the Jews as the people of God (according to Saint Peter all christians are the new Chosen People: "But ye are a chosen generation, a royal priesthood, an holy nation, a peculiar people"), ${ }^{3}$ while their kingdom became the new Promised Land; consequently, their king had to be a new David. ${ }^{4}$

If Charlemagne used to be compared to King David in texts, his grandson, Charles the Bald, king of West Francia (r. 840-877, emperor from 875) was often portrayed as David - King and Psalmist - in the illuminated manuscripts offered to him (Figure 7.1). ${ }^{5}$ Charles the Bald was also the most prominent "architect" of the royal cult of saints and relics in the early mediaeval Latin Europe, participating in numerous rituals, especially in translations of relics. ${ }^{6}$ This kind of pious activity was undoubtedly an intentional imitation of the Byzantine emperors. As a result of the supposed Constantine's translations of the relics of the Passion and of the apostles, Constantinople had already become a sacrosanct imperial capital by the sixth century. Under Justinian the ecclesiastical authors began to call the metropolis "the New Jerusalem."7 During the reign of

3 vos autem genus electum regale sacerdotium gens sancta populus adquisitionis, 1 Peter 2:9 (English text after King James Bible).

4 See Prologus Legis Salicae, 2-10; Alcuini sive Albini Epistolae, no 41, 84; Graboïs, "Un mythe fondamental"; Michałowski, "Religious Foundations of the Monarchy," 10-20; idem, "The Problem of Language," 37-39; Kantorowicz, Laudes Regiae, 53-54 and ff.; Folz, Le Couronnement impérial de Charlemagne, 97-99, 118-120; Garrisson, "The Franks as the New Israel?; Le Goff, Saint Louis, 388-39o. For Charlemagne as a new Josiah, see Admonitio generalis, 55-56. For a discussion of the notion of the "Chosen People" in the early medieval West, see also Conor O'Brien, "Chosen Peoples and New Israels." O'Brien argues that the use of the notion of "New Israel" or the "new Chosen People" does not intend to emphasise Frankish ethnic superiority over other peoples; rather it has universalising meaning. He concludes (p. 1006) that "The Carolingians did not think that the Franks were the chosen people or had replaced Old Testament Israel - at least not in any straightforward sense." In addition, O'Brien suggests (pp. 1007-1008) that "that function was to assert Christian identity as much as ethnic identity, to link a specific group of Christians to the universal church, and to draw authority and legitimation for that group (or, more usually, its rulers) from participation in the church. (...) Traditional uses of the chosen people and New Israel topos prioritize ethnicity and distinction, whereas the evidence studied in this article suggests that the language of election and Israel was essentially ecclesiological and universalizing."

5 See Robert Deshman, "The Exalted Servant," 406 ff.; Diebold, "The Ruler Portrait of Charles the Bald"; Dutton, and Kessler, The Poetry and Paintings, 42-44, 64, 81-85, 96-99; Garipzanov, The Symbolic Language, 224-228, 245-254; Schutz, The Carolingians in Central Europe, 65-73, 243-259; Steger, David rex et propheta.

6 See Michałowski, The Gniezno Summit, 119-127; Pysiak, The King and the Crown of Thorns, 16o-166.

7 See Bozóky, La politique des reliques, 94-96; Dagron, Constantinople imaginaire; idem, Naissance d'une capitale; idem, Empereur et prêtre, s.v. David; Flusin, "Construire une nouvelle Jérusalem"; Klein, "Constantine, Helena, and the Cult of the True Cross"; idem, "Sacred Relics 


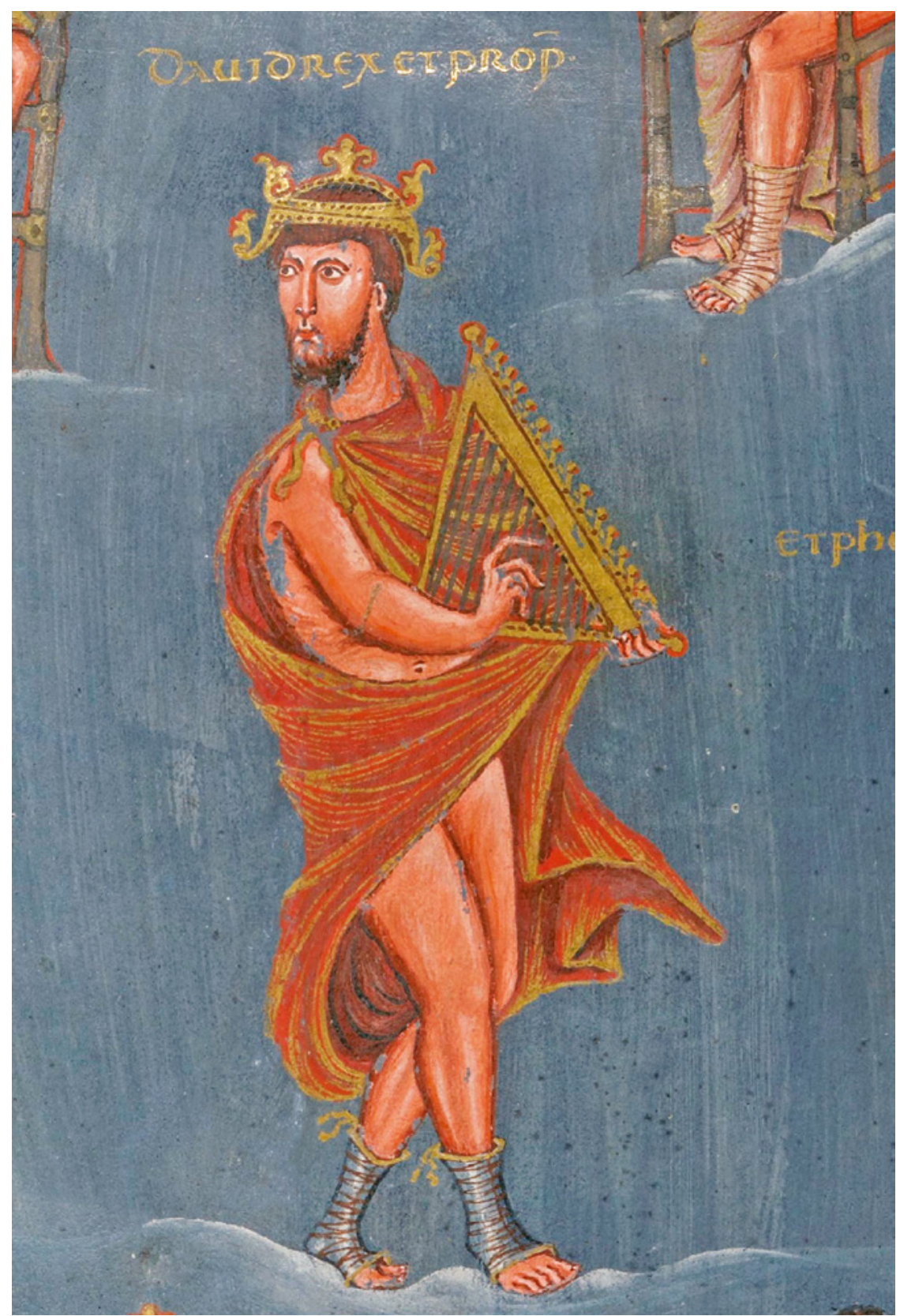

FIG URE 7.1 Charles the Bald as King David; Biblia Viviana, Tours, ca. 845-846, BnF Ms. Latin 1, fol. 215v (detail)

COURTESY OF THE BIBLIOTHÈQUE NATIONALE DE FRANCE 
emperor Heraclius (r. 610-641) this view became an intrinsic element of the Byzantine political theology, owing to the translating activity of the ruler chiefly facilitated by the wars waged by the Empire. In 626, the relics of the Passion, kept until that time in Jerusalem, got into the hands of the Persians. The Holy Cross, as well as other Passion relics, were retrieved by Heraclius in 629 , and solemnly introduced first to Constantinople, and then returned to the Holy City. The ceremonial entry of the True Cross into Jerusalem was commemorated in the liturgical memory by the anniversary feast - the Exaltation of the Holy Cross - established in its honour on September the fourteenth. In 635, when another invasion in the East was feared, the emperor decided to move the Passion relics again to Constantinople. Until the end of the Middle Ages, in both Greek and Latin traditions Heraclius became a symbolic figure of a "monarch - translator": Heraclius's translation was presented as an imitation of Christ's entry to Jerusalem or of David's bringing of the Ark of the Covenant to Jerusalem. The emperor was depicted as a pious ruler enhancing the cult of the Passion and its relics, most notably the Holy Cross. ${ }^{8}$ Due to the loss of the Holy Land conquered (in 637-638) by the Arabs, the relics had to remain in Constantinople. Consequently, the imperial capital began again to be considered "the New Jerusalem."

Yet, not only Heraclius, but also his successors consistently translated new relics to Constantinople. From the seventh century onwards, Heraclius's memory became inextricably linked with the legend of the Exaltation of the Holy Cross and in this form it was appropriated by the Western tradition. Two major texts, Sermo de Exaltatione Sanctae Crucis and Reversio Sanctae Crucis, seem to have been popular in the West in the eighth century. The latter, for a long time has been attributed to Rabanus Maurus (ca. 780-856). In his Homily LXx, recounting the retrieval of the Holy Cross from the Persians by Heraclius and its triumphant entry to Constantinople and Jerusalem, the author confirms the

and Imperial Ceremonies," 88-89; Orselli, "Simboli della città cristiana." Cf. Mergiali-Sahas, "Byzantine Emperors and Holy Relics." Briefly on Jerusalem in the ideology of the Eastern Empire and the rulers of the Latin West until the Carolingian times, see Gabriele, An Empire of Memory, 73-78.

8 See Baert, A Heritage of the Holy Wood, 133-193; Sommerlechner, "Kaiser Herakleios" (both with extensive bibliographies). See also Bozóky, La politique des reliques, 97-99; Dźwigała, "Constantine, Helena and Heraclius"; Flusin, "Les reliques de la Sainte-Chapelle"; Frolow, "La Vraie Croix"; idem, "La relique de la Vraie Croix." See also Pysiak, The King and the Crown of Thorns, $15^{2-153 .}$

9 See Borghi, In viaggio verso la Terrasanta; idem, "In viaggio verso la Terrasanta"; Ousterhout, "The Church of Santo Stefano"; idem, "Santo Stefano e Gerusalemme"; Sorbelli, "La 'Santa Jerusalem' Stefaniana." 


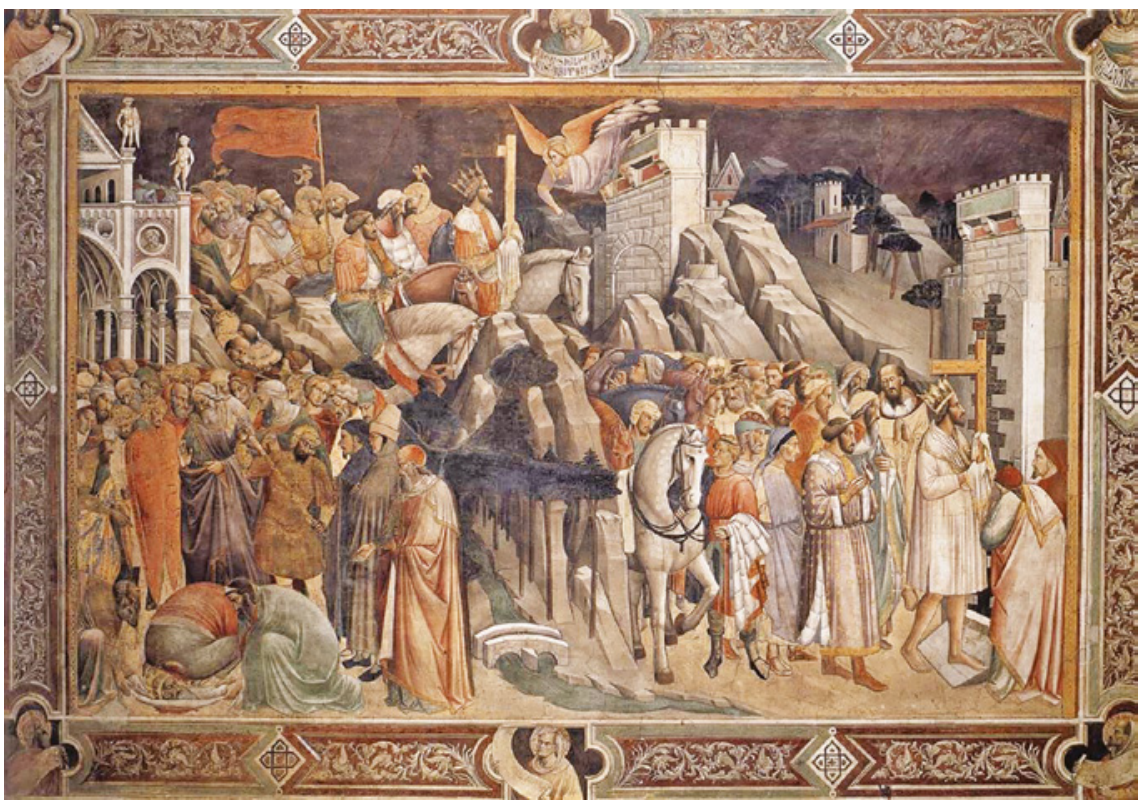

FIGURE 7.2 Agnolo Gaddi (ca. 1350-1396), Heraclius introducing the Holy Cross to Jerusalem, Florence, Basilica di Santa Croce, Leggenda della Vera Croce WIKIPEDIA COMMONS

Western reception of the Byzantine pattern of the royal translation of relics ${ }^{10}$ and reveals that the idea of the "translation of Jerusalem" was largely accepted in the Latin West." ${ }^{11}$ a good example of such a "translation of Jerusalem" motif in the Latin Church may be adduced from the group of sacral buildings of San Stefano in Bologna, erected between the eighth and the eleventh centuries, and called in medieval sources "Hierusalem Bononiensis." The Church of Santo Sepulcro there includes the only known Western replica of the Chapel of

10 See Rabanus Maurus, Homiliae, LXx: Reversio sanctae atque gloriosissimae crucis Domini, coll. 131-134. Stephan Borgehammar argues that "Reversio Sanctae Crucis as we have it was composed between the end of the seventh century and c. $75^{\circ}$, using material from the 630s." See Borgehammar, "Heraclius Learns Humility," 148-16o, esp. 159. For a critical edition of the Latin text with English translation, see ibidem, 180-191.

11 On the idea of "translation of Jerusalem" in the medieval West, see Manikowska, "Translatio of Jerusalem to Wroclaw"; eadem, Jerusalem - Rome - Compostela, 310-339 (both with a list of the most valuable monographs on that subject); Gabriele, An Empire of Memory, 79-84. 
the Confession built over the Holy Sepulchre in Jerusalem by Constantine IX Monomachos (r. 1042-1055). ${ }^{12}$

Each translation of relics was seen by the mediaeval Church as a repetition of the entry of the Ark of the Covenant to Jerusalem..$^{13}$ Consequently, every city or monastery where relics were brought could be seen by contemporary authors as a new Jerusalem and the one who was carrying them in as a new David.

In addition, the moral virtues of a king could make him worthy of being compared to David. Reporting on Charles the Bald's participation in the translation of the body of Saint Germanus in Auxerre at the feast of Epiphany of 86o, whilst Louis the German invaded the West Frankish Kingdom, Hericus of Auxerre eagerly equates the king of West Francia with David. In his view, Charles the Bald, assaulted by his older brother who coveted the throne, and betrayed by his own men, entrusted himself to God. By doing so, the sovereign proved to be "the most gentle and advised king, always deserving to be compared to David's modesty both in the art of war and peace." The author emphasizes that relying on Saint Germanus's protection while proceeding to transfer the saintly body from the old to the new sepulchre by himself, Charles the Bald was not even succoured by bishops who only assisted the ritual standing outside of the Saint's grave. ${ }^{14}$

Subsequently, the Capetian kings were also described as David's new earthly embodiment. Robert II the Pious (r. 996-1031) was equated to king David by Helgaud of Fleury. The author of Epitoma Vitae Regis Rotberti Pii describes Robert's virtues and righteousness as well as the royal sin and ensuing penitence along similar interpretative lines (e.g., Robert II's union with his second wife, queen Berthe of Blois, considered incestuous, is compared to David's affair with Bathsheba). ${ }^{15}$ Louis VII (r. 1137-1180) was called a novus David by numerous French and even Anglo-Norman authors: the abbots of Saint-Denis Suger and Odon of Deuil, as well as Étienne of Tournai, Walter Map and Serlon de Winton. ${ }^{16}$ While Robert the Pious and Louis VII were compared to David

12 See Frolow, La relique de la Vraie Croix, 76-92; Klein, "Constantine, Helena, and the Cult of the True Cross," 31-59; Klein, "Sacred Relics and Imperial Ceremonies," 88-89; Orselli, "Simboli della città cristiana"; Sommerlechner, "Kaiser Herakleios"; Mergiali-Sahas, "Byzantine Emperors and Holy Relics."

13 See Hahn, Strange Beauty, pp. 23-24

14 See Hericus Antissiodorensis monachus, Miracula sancti Germani Antissiodorensis episcopi, col. 1254. See also Michałowski, The Gniezno Summit, 117-125, 148-152; Pysiak, The King and the Crown of Thorns, $160-163$.

15 See Helgaud de Fleury, Vie de Robert le Pieux, 58, 6o, 72, 92-96, 10o, 104, 138. See also Graboïs, "Un mythe fondamental," 22-24 and nn. 48, 51.

16 See Graboïs, "Un mythe fondamental," 24-27. 
or named a "new David" as a result of their piety - thus for their personal qualities - under the reign of Philip IV the Fair (r. 1285-1314), the Carolingian model of the sacred Davidic kingship reappears in a political context. ${ }^{17}$ In 1300, during the ongoing and escalating conflict with the pope Boniface VIII, the Norman Dominican Guillaume de Sauqueville preached at the royal court, before Philip himself, a sermon Hosana filio David. The preacher affirmed that the king of France was "a son of David" - hence, a new David - as a consequence of his heavenly anointment and his thaumaturgical power of healing scrofula, and therefore he enjoyed the full sovereignty over the Papacy, as well as the Empire. ${ }^{18}$

Aryeh Graboïs, however, argues that in the course of the thirteenth century the Davidic vision of French kingship was gradually replaced by the idea of "the most Christian king" of France. This title had initially been attributed to Louis VII by the pope Alexander III in 1163, and was subsequently used by all kings of France until $1789 .{ }^{19}$ Surprisingly, in his otherwise excellent study on the use of Davidic paradigm in the Frankish and French kingdom, the author overlooked the case of Saint Louis's reign, and the latter's fervent devotion to relics which made him a "new David" in a particular way. Charles the Bald's and Charlemagne's zeal mentioned above was intentionally imitated by several later rulers, chiefly in the Holy Empire and France until the thirteenth century. ${ }^{20}$ Amongst Capetian kings, Saint Louis (r. 1226-1270) was not only the most active and passionate promoter of adoration of saints and relics, but also an enthusiast of the memory of the Carolingians. The three translations of the Crown of Thorns and other Passion relics (in 1239, 1241, and 1242), as well as the royal liturgy associated with them, undoubtedly show his intention to repeat Charlemagne's gesture as presented in French historical and hagiographical writings from the eleventh through thirteenth centuries. ${ }^{21}$ The king also fully accepted the burden of guiding his subjects to salvation, considering them a new Chosen People. ${ }^{22}$ Thanks to the bringing of the Crown of Thorns to his

17 See Strayer, "The Holy Land, the Chosen People"; Graboïs, "Un mythe fondamental," 29-30.

18 The sermon was edited in Strayer, "The Holy Land, the Chosen People," 311-314 (1971).

19 See Graboïs, "Un mythe fondamental," 28.

20 See Michałowski, The Gniezno Summit, 119-127; Petersohn, "Saint Denis - Westminster Aachen"; Petersohn, "Kaisertum und Kultakt in der Stauferzeit"; Ehlers, "Politik und Heiligenverehrung in Frankreich"; Pysiak, The King and the Crown of Thorns, 166-176, 266-278.

21 See Pysiak, The King and the Crown of Thorns, 76-135.

22 See Le Goff, Saint Louis, 216-243, 291-292, 642-672. 
Kingdom, he was seen by hagiographers as the one who made France a new Promised Land and Paris a new Jerusalem.

One could therefore expect that hagiographical writings relating Saint Louis's translation of the Crown of Thorns, as well as his hagiographical Lives (he was canonized by the pope Boniface VIII in 1297) would enthusiastically present him as a contemporary king David and a faithful follower of the biblical model. And yet, this is not the case. Amongst historical and hagiographical writings, describing Saint Louis interchangeably as a new Charlemagne, Heraclius or Josiah, ${ }^{23}$ only one source text, by a Franciscan author - Gerard of Saint-Quentin - and not a very widely known one, depicts the king as a new David.

\section{Historical and Hagiographical Sources on Saint Louis's Translation of Relics}

The ingress of the Crown of Thorns to Paris took place on the 18th or 19th of August $1239 .{ }^{24}$ The first author to report on the Holy Crown's translation was the archbishop of Sens, Gautier Cornut. In his De susceptione Coronae $D_{\text {Domin }}{ }^{25}$ he recounts that Saint Louis, carrying the relic from Vincennes castle on his own shoulders was greeted by an exclamation from the gathered crowd: "Blessed is the one who comes in God's glory and thanks to whose rule (Lat. ministerium) the Kingdom of France has been glorified by the presence of such a great treasure."26 In the fields of Parisian suburbs, near the Abbey

23 See ibidem, 388-401; The Sanctity of Louis IX, 44-49, 49-50. On the Lives of Saint Louis by Geoffrey of Beaulieu and on Louis as a new Josiah, see ibidem, 69-73, 87, 96, 111, 126-127. On the Lives of Saint Louis by William of Chartres, see 131-132. Cf. Pysiak, "Saint Louis." See also Gaposchkin, The Making of Saint Louis, 111-112, 130; Pysiak, The King and the Crown of Thorns, 370-371, 393-396, 459 .

24 Fernand de Mély (Exuviae, III, 273-274) opts for August 19th. Jannic Durand ("La translation des reliques impériales," 39) believes that the relic was brought to Vincennes on August 18th and its solemn translation to Paris took place on the next day (Friday, August 19th). For a similar view, see Charansonnet, and Morenzoni, "Prêcher sur les reliques de la Passion," 63-64.

25 See Gautier Cornut, De susceptione Coronae Domini, 26-32. Cf. Gaposchkin, "Between Historical Narration"; Pysiak, The King and the Crown of Thorns, 317-327, 334-340 and 387-429.

26 Omnium voce laudatur dicentium: "Benedictus qui venit in honore Domini, cuius ministerio regnum Franciae tanti praesentia muneris exaltatur!” See Gautier Cornut, De susceptione Coronae Domini, 31. 
of Saint-Antoine-des-Champs, ${ }^{27}$ a special high pedestal had been built where the Crown of Thorns was displayed, surrounded by other relics (most probably previously brought from Paris to welcome the Crown of Thorns), so that the populace could behold it before it was brought into the town. The relic, accompanied by the bishops and monks from the Parisian monasteries, and probably enclosed in a golden lipsanotheca, ${ }^{28}$ was shown to the faithful. In addition, a sermon was given explaining what joy it was to everyone. ${ }^{29}$ Then, Louis IX and the eldest of his brothers, Robert, count of Artois, barefoot and dressed in humble tunics, carried the Crown of Thorns into the town on a specially executed feretory. ${ }^{30}$ They walked at the very end of a pageant formed by prelates, monks, and lay clergy, and accompanied by knights and barons. The Crown was first taken to Notre-Dame Cathedral and, having sung the lauds in honour of Our Lady, the procession with the Holy Crown continued to the royal palace (Palais de la Cité). The relic was solemnly deposited in the royal oratory of Saint Nicholas. ${ }^{31}$ As the news of the ceremony spread far beyond Paris, people began to gather at the Fields of Saint-Antoine where the ostensio of the Crown of Thorns had been performed, in order to venerate the place where the Holy Crown had stayed and they kissed the pedestal on which the relic had been displayed. According to Gautier Cornut, numerous miracles took place there thanks to the saintly power of the holy diadem (Lat. sacri diadematis) and the fervent faith of the devout people. ${ }^{32}$ This is how Gautier Cornut's account

27 The Abbey of Saint-Antoine-des-Champs, established in 1198 by Foulques de Neuilly as a hermitage intended to return fallen women to virtuous life. In 1204 the Cistercian rule was adopted there and from 1229 the monastery was under protection of Louis IX and became a royal abbey. See Bonnardot, L'Abbaye royale de Saint-Antoine-des-Champs; Émile Raunié, Abbaye royale de Saint-Antoine-des-Champs; Szollosi, Les moniales de SaintAntoine-des-Champs.

28 This seems to be indicated by the word loculus used by Gautier Cornut, which he used earlier to denote the golden lipsanotheca.

29 Octava die, extra muros, juxta ecclesiam B. Anthonii, in campi planitie construitur eminens pulpitum, astantibus pluribus praelatis, ecclesiarum conventibus indutis sericis, exhibitis sanctorum pignoribus, in tanta populorum frequentia quantam Parisius exierit. Monstratur loculus ex pulpito, dieifelicitas et causa gaudii praedicatur. See Gautier Cornut, De susceptione Coronae Domini, 31.

30 The fact that such a procession feretory (Lat. archa ferrata) was made is confirmed by the royal accounts. See Itinera, Dona \& Hernesia Ludovici IX, 601.

31 Post haec intra muros civitatis infertur a rege et fratre suo, discalciatis ut prius, et praeter tunicas vestimentis depositis. Omnes etiam praelati cum clericis et viris religiosis, necnon et militibus, nudis pedibus antecedunt. [...] In potificalem ecclesiam beatae Virginis inducitur, ubi persolutis Deo et beatissimae Matri ejus devotis laudibus, cum thesauro nobili solemniter ad regis palatium revertuntur. Collocatur in capella regia beati Nicolai cum multo gaudio Domini corona. See Gautier Cornut, De susceptione Coronae Domini, 31.

[...] per virtutem sacri diadematis et propter devotionem fidelium. See ibidem. 
ends. Another hagiographer, Jacques de Dinant reports in addition that the town was decorated with silks, carpets and canopies and that all over Paris one could smell the incense and hear the bells, as well as the sounds of musical instruments (Lat. cymbalis et campanis) and hymns sung in the organum style. ${ }^{33}$

Another account of the event was written several years later by a Franciscan author, Gerard of Saint-Quentin. It was composed after Sainte-Chapelle had been consecrated (1248), which event is not mentioned either by Gautier Cornut or Jacques de Dinant. Despite the fact that Gerard's account relates the course of the translation in much less detail than the booklet by the archbishop of Sens, it offers several details of the ideological interpretation of the translation liturg absent from the writings of Gautier and Jacques. Gerard describes only the ritual of translation performed in Paris (ignoring the entry of the Crown of Thorns to Sens on August 11th and the liturgy celebrated there described in minute detail by Gautier Cornut - the archbishop of the city). He also makes no mention of any earlier events (acquisition of relics from the Latin emperor Baldwin II and their purchase from Venetian moneylenders), nor provides any dates. Nevertheless, we learn from his text that the day of the relics' translation to Paris and their public display (Gerard unquestionably means the ostensio outside the Saint-Antoine's Gate described by Gautier Cornut) had been chosen by Louis IX himself. The author reports that on that occasion, not only the people of Paris, but also those from all over the kingdom flocked there; the bishops wearing the pontifical gowns arrived from various towns, as well as the monks and lay clergy from Paris and the neighbouring churches and monasteries. Among those present at the ostensio was Louis IX depicted as "our David, not mounted on a precious and tall horse wearing rich tackle, but walking on his own bare feet to joyfully introduce the Lord's Ark to his town, Paris." ${ }^{34}$ According to Gerard, after everyone had come to the place where the Crown of Thorns was to be demonstrated, a sermon was delivered to the people, calling them to renounce old sins and to avoid new ones in the future. Later, the relic was carried around the pedestal so that everyone could see it. ${ }^{35}$ Subsequently, the king placed the relic on his own shoulders, brought it to Paris and - following the procession of the lay and ecclesiastical clergy, the rich and the poor, singing lauds and hymns, illuminated by countless

33 See Iacobus de Dinant, Excerpta e Tractatu de translatione beatae Genovefae virginis, 141.

$34[. .$.$] adest inter eos et noster David rex Ludovicus, non precioso et eminente equo subvectus,$ non phaleris adornatus, sed pedes incedens et discalciatis pedibus, quasi archam Domini in civitatem suam Parisiensem cum gaudio mox ducturus. See Gerard de Saint-Quentin, Translatio Sancte Corone Domini Ihesu Christi, 105. 
candles - carried the Crown of Thorns to the royal palace to have it stored in a magnificent basilica (Sainte-Chapelle) built by the king soon afterwards. ${ }^{36}$

The last author describing the translation who may with certainty be considered contemporary to the events (though not an eyewitness) is the English Benedictine monk, Matthew Paris. His account, however, does not contribute much; he merely states that the relic was solemnly introduced to Paris in a procession to the sound of the bells, and reverently deposited in the chapel royal. ${ }^{37}$

\section{$3 \quad$ Homiletical Interpretation of Saint Louis as New David and Paris as New Jerusalem}

Now, it behoves us to analyse in greater detail De susceptione Coronae Domini. ${ }^{38}$ In its homiletical part, the author of this text encourages the Church of Gaul and all the French people to thank God for having bestowed such a marvellous treasure on the Kingdom. ${ }^{39}$ The Crown which Christ, the head of the Christian Church (Lat. caput nostrum), allowed to be put on His head for the sake of the salvation of humanity, God has this day and age given to the French

$36 \quad$ Quibus ita gestis, universis clericorum ac religiosorum choris precedentibus ac civitatem Parisiensem cum cantu et hympnis ingredientibus, necnon et ceteris tam nobilibus quam aliis qui turmatim advenerant cum luminarium multiplicitate et laudum immensitate comitantibus, rex ipse discalciatus incedens, et Coronam dominicam in humeris suis gestans, humiliter et devote subsequitur, sicque cum plausu omnium ad ipsius regis palatium deportatur ubi in edificata non multo post per eundem regem basilica, precioso scemate constructa, honorifice reservatur. See ibidem.

37 See Matthew Paris, Chronica majora, IV, 75-76.

38 In her brilliant paper, Cecilia Gaposchkin argues that De susceptione Coronae Domini (until recently attributed to Gautier Cornut in its entirety) is in fact composed of two originally separate texts: a "historical" one, authored by Cornut, and a homiletical one, composed by an unknown author not before August 1242 (the date of the last of three translations of the Passion relics to Paris), but certainly before Saint Louis's death (1270). According to Gaposchkin, these two texts were merged into a single account "sometimes in the thirteenth century." In the following part of my paper, I will present and analyse the hortatory part of De susceptione. Until recently, it has widly been considered a sermon, but Gaposchkin convincingly demonstrates that it is much more likely that it was written as liturgical lections. See Gaposchkin, "Between Historical Narration," 93-110, esp. 113120. For a new edition and English translation of Cornut's original text, see Gaposchkin, "Between Historical Narration," 121-139.

39 Gratias tibi Deus cuius immensa bonitas [...] terram nostram incomparabili thesauro ditavit, genti et regno quasi summum post multos accumulavit honorem! Laetetur in iis sacris solemnis Ecclesia Gallicana, et tota gens Francorum. See Gautier Cornut, De susceptione Coronae Domini, 27. 
people. ${ }^{40}$ As Christ chose the Promised Land to show mankind the Mystery of Redemption, we read in the account of the sermon, so He chose Gaul to show the triumph of the Passion, in order that the whole world, from the East to the West, could venerate the Saviour. ${ }^{41}$ France was distinguished in this way owing to the religious fervour of king Louis $\mathrm{IX}^{42}$ whose rule (Lat. imperium) has been legitimized in the greatest and most powerful way possible: namely, it was confirmed by God himself, who deigned to crown France and its king with the crown He had worn Himself.43 That is why king Louis has to be obeyed - such is the apostolic order. ${ }^{44}$ When participating in the translation of the Crown of Thorns, or in the annual feast celebrated in its commemoration, or even having the privilege of looking at this salvific relic, the faithful should imagine Christ crowned with the Crown of Thorns, considering the words of the Song of Solomon: "[...] Go forth, $\mathrm{O}$ ye daughters of Zion, and behold king Solomon with the crown wherewith his mother crowned him in the day of his espousals, and in the day of the gladness of his heart." 45 The reign of Louis IX, understood as a royal service (Lat. ministerium), brought great joy thanks to obtaining this magnificent relic, which, according to the text, was known well to the crowds of the faithful who came to the translation ceremony." Louis IX, in turn, is reported to have believed that the entire merit was owed to the special grace of God. Christ wished His crown to be specially venerated by the faithful on Earth because when He comes back for the Last Judgement, he will wear it again

40 Haec est illa praeclara festivitas, in qua missum sibi a Domino pretiosissimum munus Francorum terra suscepit, illam videlicet sacrosanctam spineam Coronam, quam caput nostrum, Dominus Iesus Christus, pro nobis factus obediens Patri usque ad mortem crucis, tempore Passionis ipsius, venerando capiti suo per manus impiorum permisit imponi. See ibidem.

41 Sicut igitur Dominus Iesus Christus ad suae Redemptionis exhibenda mysteria terram promissionis elegit, sic ad Passionis suae triumphum devotius venerandum nostram Galliam videtur et creditur specialiter elegisse, ut ab ortu solis ad occasum laudetur nomen Domini, dum a climate Greciae, quae vicinior dicitur Orienti, in Galliam, partibus Occidentis contiguam et confinem, ipse Dominus ac redemptor noster suae sacratissimae Passionis sancta transmitteret instrumenta. See ibidem.

42 Honoratum enim gestis insignibus per multa tempora regnum Franciae, tempore nostro, per sedulam regis Ludovici, necnon et religiosae matris suae Blanchae vigilantiam. See ibidem, $27-28$.

$43[$ Deus] Corona capitis sui cum multa gloria et honore multiplici dignatus est coronare. See ibidem, 28.

44 Verum, quia regis ad hoc accessit imperium, cui, tanquam praecellenti, secundum apostolum oportet obedire. See ibidem.

45 Egredimini \& videte, filie Syon! Regem Salomonem in diademate quo coronavit eum mater sua (Song of Songs [Canticle] 3:11) (English text after King James Bible). 
to show everyone his royal insignia. ${ }^{46}$ Louis IX rejoiced that God had chosen his very kingdom, Gaul, where - thanks to God's grace - the faith blossoms stronger than elsewhere and the mystery of Salvation is venerated in the most pious way, to demonstrate to the human eyes this great treasure and honour. ${ }^{47}$ As De susceptione uses the word praeelegerat, one may venture an eschatological interpretation of his discourse: God had chosen Gaul as a country where the work of Salvation is to be ultimately performed at the end of times. The author of De susceptione evidently aims at a sanctification of the whole France as the new Promised Land and its inhabitants as the new Chosen People. This is suggested by the statement that Gaul "had been chosen" by God as the place where Christianity was particularly ardent. The choice of Gaul as the place where the Passion insignia were revealed - including the Crown of Thorns which is to be venerated in France until the end of this age, Christ's Second Coming, and the Final Judgement - is also a sign of His grace. In this way France becomes the New Israel:

Like He chose the Promised Land to reveal the mystery of Redemption, as it can be seen and should be believed, so Our Lord, Jesus Christ, has chosen our Gaul in order that the triumph of His Passion be piously venerated there, so that the Lord's name be praised from the East to the West. For Our Lord and Saviour brought the holy signs of His Passion from Greece which, as it is said, neighbours with the East, to Gaul, which neighbours with the West. And so, thanks to the participation in this honour, He made these two countries equal. ${ }^{48}$

Finally, one should note that in De susceptione the Crown of Thorns is directly identified with the royal diadem. When Cornut describes the miracles that

$46 \quad$ His auditis, rex prudenter intelligens id a Domino fieri, gavisus est in hoc quod ille qui Coronam eandem pro nobis gesserat in opprobrium, volebat eam a suis fidelibus pie et reverenter honorari in terris, donec ad iudicium veniens eam suo rursus imponeret capiti iudicandis omnibus ostendam. See ibidem, 29.

47 Gaudebat igitur quod ad exhibendum honorem huiusmodi suam Deus praeelegerat Galliam, in qua per ipsius clementiam fides viget firmiter, et cultu devotissimo salutis nostrae mysteria celebrantur. See ibidem.

48 Sicut igitur Dominus Jesus Christus ad suae redemptionis exhibenda mysteria terram promissionis elegit, sic ad passionis suae triumphum devotius venerandum nostram Galliam videtur et creditur specialiter elegisse, ut ab ortu solis ad occasum laudetur nomen Domini, dum a climate Greciae, quae vicinior dicitur Orienti, in Galliam, partibus Occidentis contiguam aut confinem, ipse Dominus ac Redemptor noster suae sacratissimae passionis sancta transmitteret instrumenta. Et sic, veluti compartitis honoribus, terrae alteri alteram adequavit. See Gautier Cornut, De susceptione Coronae Domini, 27. 
God performed in the place of the ostensio of the Crown of Thorns near the church of Saint-Antoine, he specifies that they occurred thanks to the power of the holy diadem (and to the piousness of the faithful assembled there whose faith was rewarded). ${ }^{49}$ Thus the author stresses strongly the merits of Louis IX for the translation of the Crown of Thorns as well as the similarity of the king to Christ. The call with which Saint Louis was greeted when bringing the Crown of Thorns to Paris is modelled after the words uttered, according to the Gospel of Saint Matthew (Matthew 21:9), by the populace when Christ was entering Jerusalem: "Blessed is the One who comes in God's name" (Lat. Benedictus qui venit in nomine Domini). Within the context of a hagiographic description of the translation of the relics, especially as they were Christ's relics, it may, of course, be understood as a symbolic repetition of Christ's entrance to Jerusalem. However, the author develops the quotation from the Gospel of Matthew so that it clearly refers to king Louis and makes him into an image, almost a figure, of Christ on Earth. In the homiletical part of De susceptione, its author included also a fragment from the Gospel of Saint John, indicating its concordance with the Gospel of Saint Mark and Saint Matthew (John 19:2; Mark 15:17; Matthew 27:29), which describes clothing Christ with a purple mantle and crowning Him with the thorns. Moreover, he added the quotation from Saint Augustine's The City of God (XVIII, 23) where it is said that in this way the prophecy of the Erythraean or Cumaean Sibyl has been fulfilled.

Some of the ideological motifs present in De susceptione Coronae Domini were later developed in the description of the three translations of the Passion relics written by Gerard of Saint-Quentin, which also contains new elements, equally interesting and important for the ideology of the royal sacral power of the Capetians. When describing the translation of the Crown of Thorns, Gerard presents Saint Louis as the new David (calling him "our David, king Louis") who brings the Crown to Paris, just like the biblical king of Israel brought the Ark of the Covenant to Jerusalem..$^{50}$ When describing the translation of the relics brought to Paris by the Franciscan legation in 1242, Gerard once again compares the Capetian capital to Jerusalem. ${ }^{51}$ Thus also in this account

$49[. .$.$] per virtutem sacri diadematis et propter devotionem fidelium. See Gautier Cornut, De$ susceptione Coronae Domini, 31.

50 [...] adest inter eos et noster David rex Ludovicus, non precioso et eminente equo subvectus, non phaleris adornatus, sed pedes incedens et discalciatis pedibus, quasi archam Domini in civitatem suam Parisiensem cum gaudio mox ducturus; Gerard de Saint-Quentin, Translatio Sancte Corone (Exuviae, III, 105).

$5^{1}$ Nec mora, congregatis ad urbem Parisiensem universis fere regni presulibus et prelatis, ipsa civitas quasi altera Iherusalem tantis oppigeranda magnalibus cum omni apparatu et decentia adornatur. See ibidem. 


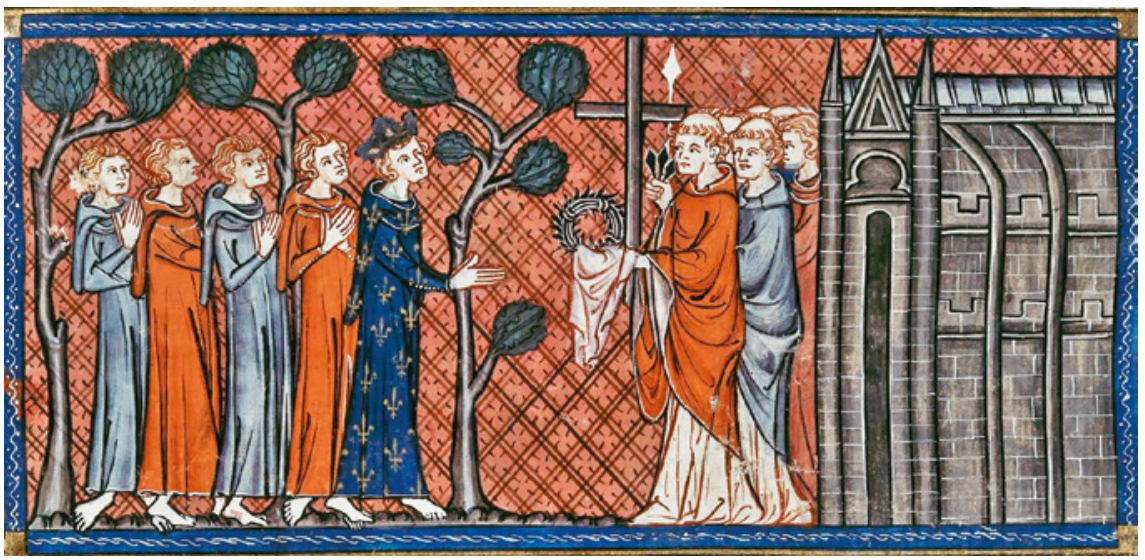

FIGURE 7.3 Saint Louis going towards the Crown of Thorns; Les Grandes chroniques de France, Paris 1332-1350; British Library, Royal 16 G VI, fol. 395 WIKIPEDIA COMMONS

Louis IX - as the author and performer of the translation - becomes a figure of Christ (like David before him), while Paris represents the New Jerusalem, and France - the new Israel.

The topic of translation of Jerusalem to Paris thanks to the translation of the Passion relics there can also be found in the Chronica majora by Matthew Paris although it is developed there in a different way. The author adduces the example of emperor Heraclius, an emblematic figure and model of a Christian monarch embracing and organizing the cult of the Passion relics. The choice of Heraclius as the historical model of a ruler who organized the cult of the Passion relics is particularly apt, but not original; we have already seen it in Carolingian times, when Heraclius was frequently described as the one who venerated the True Cross and established the most important feast in its honour, the Exaltation of the Holy Cross (Lat. Exaltatio Crucis). Nonetheless, in his comparison of Louis IX to Heraclius, Matthew does not evoke the idea of establishing feasts in honour of the relics, but instead stresses the analogies between the translation ceremonies. He reports that during the translation of the Holy Cross on Good Friday in 1241, when everyone piously venerated the True Cross, the king, after having served the prescribed penance practices, following the example of "the noblest and victorious Heraclius Augustus, took [the Cross] to the city of Paris." ${ }^{22}$ During the procession to the Parisian cathedral, in which Louis carried the relic himself, he imitated Heraclius too:

$52[\ldots]$ cum omnes veneranter ac devote ipsam [Crucem] adorassent, rex nudus pedes, in laneis, discinctus, capite discoperto, triduano jejunio anticipato, edoctus exemplo 
[the bishops] wished that yon [i.e., the king], thanks to whose wisdom such a great glory [i.e., the True Cross] was gained [in France], wields with piousness [the True Cross] in the image of Heraclius, in the presence of the populace. ${ }^{53}$

Saint Louis is the new Heraclius and like him he brings the Holy Cross to the (new) Jerusalem for, like Heraclius, it was the king who brought the translation about. That is why, and - according to Matthew Paris this is also the opinion of the hierarchs - the king has the right to touch the True Cross and bring it to his town and temple. Matthew includes a similar description in his Historia minor. ${ }^{54}$ The descriptions of the demonstration of the relics at the suburb of Saint-Antoine where Saint Louis personally displayed the Holy Cross to the faithful assembled there, immediately brings to mind the depiction of Heraclius's translation of the True Cross in Jerusalem. Matthew Paris mentions the cry "Behold the Cross of the Lord" (Lat. Ecce Crucem Domini) which was uttered during the ostensio by the bishops assembled around it. The same cry was said to have been heard when Heraclius was bringing the Cross to Jerusalem freed from the Persian rule. It should be added, however, that the text of Chronica majora differs from Matthew's drawing accompanying the narrative. On the drawing the cry Ecce Crucem Domini comes out of the mouth of the king holding the relic in his own hands..$^{55}$

The parallel between Heraclius and Saint Louis performing the translation of the Passion relics was certainly not accidental for Matthew and it did not concern only the king of France but served as a model situation as well. In particular, Matthew used it also with regard to the translation of Christ's

nobilissimi triumphatoris Eraclii Augusti, versus Parisiacam urbem et usque ad ecclesiam beatae Virginis cathedralem bajulavit. See Matthew Paris, Chronica majora, IV, 90-91 (bold type: JP).

53 Et hoc circumspecto ipsis praelatis sic volentibus factum est, ut [ab] ipsi[s], quorum prudentia tanta gloria fuerat adquisita, esset etiam circumstante populo ad instar Eraclii, de quo fecimus mentionem, illo modo veneranter attrectata. See Matthew Paris, Chronica majora, IV, 91 (bold type: JP).

54 [...] dominus rex Francorum Crucem Domini, quam ab imperatore Constantinopolitano $B$ [aldewino] sibi pro maximo thesauro comparaverat, ab ecclesia Sancti Antonii nudus pedes et in laneis cum summa humilitate ac sollepmni processione portavit; edoctus exemplo Christianissimi imperatori Eraclii. See Matthew Paris, Historia minor, II, 446.

$55[\ldots]$ crucem ipsam in altum $[$ rex $]$ elevavit lacrimis abortus, incipientibus qui praesentes erant praelatis voce altissima, 'Ecce crucem Domini'. See Matthew Paris, Chronica majora, IV, 9o. The drawing is kept in Cambridge. See Corpus Christi College, Ms. 16, fol. 141r. 
Holy Blood performed in 1247 by the English king Henry III. ${ }^{56}$ This monarch, too, is seen as a new Heraclius while carrying the Holy Blood in procession to Westminster Abbey. The chronicler states overtly that the king of England followed the example of both Heraclius and Saint Louis:

Our Lord the King, being the most Christian ruler, taking an example of the most pious and victorious emperor Heraclius Augustus, who performed the Exaltation of the Cross, and of the contemporary king of the Franks, who honoured this very Holy Cross in Paris, as we have it described above, full of piousness and regretting his sins, on the eve of Saint Edward's Day fasted on bread and water and took nightly vigils praying in the light of many candles, and prudently prepared himself for the celebrations on the morrow. ${ }^{57}$

Thus, Matthew views Louis IX not only as an imitator of emperor Heraclius but as an example for other monarchs to follow. The fact that the monarch played an active role in the enhancement of the cult of Passion relics makes him a contemporary Heraclius; yet, not only does he follow the example of the ancient Roman emperor but himself becomes a new example for his contemporaries.

Let us return to Gerard of Saint-Quentin. In his account of the translation of Passion relics we find also another very interesting topic connected with the elevation of France, described earlier in De susceptione. Gerard continues the topic of France as the new Chosen People, i.e., by comparing the celebrations of the translation of the Passion relics to the introduction of the Ark of the Covenant to Jerusalem by king David, and calls Paris New Jerusalem. However, he admits that God's grace was already bestowed on the kingdom of France earlier and again it was an unquestionable merit of Louis IX:

When the most Christian king, Louis [...] - whose nobility of the spirit was no lesser than the perfection of his body, increased the power of his kingdom (Lat. regni imperio) and multiplied its wealth much more

$5^{6}$ On the translation of the Holy Blood to Westminster in 1247, see Vincent, The Holy Blood; Pysiak, "The Cult of Passion Relics."

57 Dominus autem rex, utpote princeps Christianissimus, ab Augusto Eraclio victoriosissimo ac piissimo imperatore, crucem sanctam exaltante, et a rege Francorum tunc superstite, crucem eandem, ut praescribitur, Parisius honorante, sumens exemplum, devoto spiritu ac contrito in vigilia sancti $E[d w a r d i]$ in pane et aqua jejunans, et nocte vigilans, cum ingenti lumine et devotis orationibus se ad crastinam sollepmnitatem prudenter praeparavit. See Matthew Paris, Chronica majora, IV, 641. Cf. Matthew Paris, Historia minor, III, 302: Revocavit enim ad memoriam historiam de imperatore Eraclio Crucem ad portas Jerusalem bajulante. 
than his predecessors - was elevated by the Lord, he obeyed the commandments of the Supreme Lord in the humility of spirit, following the principles of fairness [and was] both the expander and protector of the freedom of the Church. And as it is said in the divine law: "And when the Lord gave you the cities big and strong, houses full of all the riches, and thou shalt eat and be full, beware lest thou forget the Lord"58 [...], the more praiseworthy was his [Louis's] gentleness and the more pleasing to God, his humility. [...] So it came to pass that He who knew from the beginning the work of every man and who rewards everyone according to their merit, as if already approving the ways of his [life], gave him a sign of special love, which appears to be an indication of stability of his kingdom and a sufficient sign of the probable, if he perseveres in doing good, future happiness in Heaven. ${ }^{59}$

After this apology of the perfect reign of Louis IX, Gerard of Saint-Quentin begins the account of the translation of the Crown of Thorns to France. Therefore bringing the relic to the Capetian capital was not only a result of the prudence and thrift of the king who took advantage of, as it may seem, accidental circumstances to obtain such a magnificent relic, free it from the hands of the creditors and prevent Christianity from losing it, but also a consequence of king Louis's virtues that were rewarded by God who, seeing the king's merits, granted him and his kingdom the greatest prize. God gave Louis IX the Crown of Thorns as an indication that his state would continue to prosper and

$5^{8}$ Paraphrase of Deuteronomy 6:10-12: And it shall be, when the Lord thy God shall have brought thee into the land which he sware unto thy fathers, to Abraham, to Isaac, and to Jacob, to give thee great and goodly cities, which thou buildedst not, / And houses full of all good things, which thou filledst not, and wells digged, which thou diggedst not, vineyards and olive trees, which thou plantedst not; when thou shalt have eaten and be full; / Then beware lest thou forget the Lord, which brought thee forth out of the land of Egypt, from the house of bondage (English text after King James Bible).

59 Cum christianissimus Francorum rex Ludovicus [...] non minus animi nobilitate quam carnis generositate conspicuus, super predecessorum suorum magnificentiam dilatato regni imperio et multiplicata rerum opulentia esset a Domino sublimatus, in preceptis Altissimi ambulavit, in humilitate spiritus, justicie norma, libertatis ecclesiastice promotor pariter et patronus. Et sicut in divina lege precipitur: Cum dederit tibi Dominus civitates multas et firmas, domos plenas cunctarum opum, et comederis et saturatus fueris, cave ne obliviscaris Dominum Deum tuum [...] tanto laudabilior esset ipsius mansuetudo et acceptabilior apud Dominum humilitas. [...] Unde factum est ut ille qui ab inicio novit opera singulorum et unumquemque remunerat secundum suorum exigentiam meritorum, quasi vias ejus jam approbans precipue dilectionis eidem tribueret intersignum, quod et regni videbatur stabilimenti presagium, et satis probabile si perseveret in bono future beatitudinis argumentum. See Gerard de Saint-Quentin, Translatio Sancte Corone (Exuviae, III, 102-103). 
a sign that, if he kept to God's paths, the king would even become a saint (Lat. futura beatitudo).

\section{Liturgical Sources on Saint Louis as New David and Paris as New Jerusalem}

The first known "translation of Jerusalem" was performed in Byzantium when emperor Heraclius took the Passion relics (regained from the Persians) from Jerusalem, still threatened with a Persian invasion, to Constantinople. After the Muslim conquest of the Middle East, which took place during the following few years, the Byzantine historiography considered this "translation of Jerusalem" as a lasting result of God's plan. ${ }^{60}$ In the tenth century, the Byzantine emperors, unable to defeat their Islamic neighbours and restore Greek rule on the territories lost by the Empire, contented themselves with the retrieval of the most precious relics which had been left in lost provinces. A new idea of the imperial triumph was conceived in Constantinople: it was the triumphal entry of relics to the imperial metropolis. ${ }^{61}$

The hagiographers recounting the translation of the Crown of Thorns, the True Cross and the other Passion relics to France, clearly refer to Byzantine tradition in their descriptions of Paris as a new Jerusalem. Gerard of Saint-Quentin says it overtly, while De susceptione only alludes to this idea. The Kingdom of France is depicted as a new Terra Promissionis chosen by God - it was there that the triumphal insignia of the Passion were to be venerated. Thus, with the translation of the Crown of Thorns, the Holy Land was translated to the West.

This view can also be found in two hagiographical Lives of Saint Louis used for lections (Lat. lectiones) in the earliest liturgy of the feast of Saint Louis and in the sermons delivered on this festivity. ${ }^{62}$ Such readings come from two lectionaries probably written in ca. 1300 . The former recounts the translation of the Crown of Thorns in lection seven where it briefly describes by what means the Holy Crown, the True Cross, and the Holy Lance were brought from Constantinople to France, then transferred by Saint Louis to Paris. In addition

6o See Baert, A Heritage of the Holy Wood; Bozóky, La politique des reliques; Dagron, Naissance d'une capitale; idem, Constantinople imaginaire; Flusin, "Construire une nouvelle Jérusalem"; idem, "Les reliques de la Sainte-Chapelle"; Frolow, "La Vraie Croix."

61 See Engberg, "Romanos Lekapenos"; Patlagean, "L'entrée de la sainte Face d'Edesse à Constantinople en 944"; Weitzmann, "The Mandylion and Constantine Porphyrogenitus."

62 On the sermons, especially given by cardinal Odo de Châteauroux, about the Passion relic similar in their ideological aspect with the narratives and the liturgy of the feasts in their honour, see Charansonnet and Morenzoni, "Prêcher sur les reliques de la Passion." 
it explains by what means Sainte-Chapelle was built by the saintly king in order to store the relics, in what manner the king established three liturgical feasts in their honour, and how the liturgical service was entrusted by the king to the Dominicans and Franciscans. ${ }^{63}$ We can find similar content in a sermon for the feast of Saint Louis supposedly written by Guillaume de Saint-Pathus. ${ }^{64}$ The narrative is much more detailed in a sermon for the feast of Saint Louis found in another Parisian lectionary: Fuit in diebus nostris in Francia rex christianissimus. ${ }^{65}$ A striking feature of the second sermon is the confusion of the order of the two translations. According to its author, first the True Cross was brought to Paris and only afterwards the Crown of Thorns. In the part relating the translation of the True Cross, the hagiographer equates Saint Louis bringing the Cross to Paris to David bringing the Ark of the Covenant to Jerusalem, and to Moses entering in the Promised Land:

Thus the king, as if he were a second David playing in front of the Ark [of Covenant], carrying the priceless treasury on his shoulders, and, like as a second Moses, since reaching his [Promised] Land was sacred, having his shoes removed, walked barefoot. 66

Then, passing on to the translation of the Crown of Thorns, the author presents Saint Louis performing the ostensio of the Holy Cross to his subjects and this time calls him the second Constantine. ${ }^{67}$

63 See Beatus Ludovicus, Capitulum viI, 124 (Lat.), 125 (Eng.).

64 See Guillaume de Saint-Pathus, Sermon en l'honneur de Saint Louis, cap. 22, 286: Talis fuit beatus Ludovicùs, ut patet devocione ejus ad sacras reliquias et ad divinum officium. Capellam speciosissimam pro sacris reliquiis miro scemate edificavit que XL millia librarum Turonensium et amplius constituit, et thecam speciosissimam, in qua ipsas reliquias posuit, fecit, que $C$ millibus libris Turonensium et amplius constitit. Diem anniversariam pro ipsis sollempnizari instituit, unam per Predicatores, scilicet festum Corone sacre, et aliud per fratres Minores scilicet sancte Crucis et aliarum omnium insimul. Hec fuit ejus devocio ad sacras reliquias.

65 Beati Ludovici vita partim ad lectiones partim ad sacrum sermonem parata, RHF, 167-176. See BnF, Ms. Latin 11754, BHL 5050. On liturgical sources concerning the translations of the Crown of Thorns and other Passion relics to Paris, see Pysiak, The King and the Crown of Thorns, 317-327, 334-385.

66 Rex autem, velut alter David ante archam ludens, thesaurum impreciabilem propriis gestans humeris, et velut alter Moyses, quia sacrosanctum erat quod in terram suam venerat, sublatis calciamentis pedibus incedebat nudis. See Beati Ludovici vita partim ad lectiones partim ad sacrum sermonem parata, 171.

67 Et in procinctu itineris, valefacto ecclesiae congregatae, videre potuit clerus Parisiensis alterum Constantinum, non tumore superbiae sublevatum, sed crucifixum corde, signatum 
The majority of the liturgical offices and sermons for Saint Louis's feast days were meticulously examined by M. Cecilia Gaposchkin, who initiated her research with the most widely used rhymed one, Ludovicus decus regnantium. ${ }^{68}$ Gaposchkin's research is focused on several offices written in honour of Saint Louis: Ludovicus decus regnantium, Nunc laudare, Lauda celestis regio, Francorum rex, Exultemus omnes and Gaudeamus omnes, ${ }^{69}$ as well as on sermons composed by cardinal James of Viterbo, by Jacob of Lausanne, and finally by John of Aragon, ${ }^{70}$ a royal prince, archbishop first of Toledo, then of Tarragona and patriarch of Alexandria in the early fourteenth century, and lastly on two hagiographical Lives of Saint Louis: Gloriosissimi regis and Beatus Ludovicus, both presumably intended for liturgical use. ${ }^{71}$ According to Gaposchkin, when composing his text, the Dominican author of Ludovicus decus regnantium follows an earlier office (known in three slightly different versions: one of Cistercian origin, one of secular origin - known for being in use by secular clergy in the ecclesiatical province of Sens, especially in Paris diocese - and a Benedictine one, known from Saint-Denis and Saint-Germain-des-Prés), Lauda celestis regio, ${ }^{72}$ but expands its royal significance - the office in question was celebrated at the Royal Court, and Philip the Fair is thought to be involved in its creation. ${ }^{73}$ Already in the Cistercian office Lauda celestis regio Louis IX was compared to Josiah, Solomon, David, Manasseh, Jacob, and Ahasuerus, praising Saint Louis as being as firm as David in faith. ${ }^{74}$ In her discussion of

humero, nudis pedibus incedentem, gestantem in manibus dominicae Crucis ligneum. See Beati Ludovici Vita partim ad lectiones partim ad sacrum sermonem parata, 172.

68 For the first presentation and (not exhaustive) analysis of this office from liturgical and musicological point of view, see Epstein, "Ludovicus Decus Regnantium." For a more recent study of this text and its ideological content, see Gaposhkin, "Ludovicus Decus Regnantium."

69 See Gaposchkin, "Philip the Fair"; eadem, The Making of Saint Louis; eadem, "Louis IX et la mémoire liturgique"; eadem, "The monastic office for Louis IX"; eadem, Blessed Louis, the Most Glorious of Kings; eadem, "Louis IX and Liturgical Memory." It is worth noting that Gaposchkin omitted the sermon Fuit in diebus nostris in Francia rex christianissimus (see nn. 65, 66 and 67). On David's figure in Lauda celestis, see Gaposchkin, The Making of Saint Louis, 130, 139; 104, 106-107 (Nunc laudare); 111-112, 114-115, 117 (Ludovicus decus regnantium).

70 Sermons by Jacob of Lausanne were edited in Gaposchkin, Blessed Louis, the Most Glorious of Kings, 227-245 (Rex sapiens); 247-299 (Videte regem Salomonem). For sermons of James of Viterbo and John of Aragon, see Gaposchkin, "Talking about Kingship."

71 Both of them were first published by M. Cecilia Gaposchkin. See Gaposchkin, Blessed Louis, the Most Glorious of Kings, 27-81 (Gloriosissimi regis); 159-207 (Beatus Ludovicus).

72 See Gaposchkin, "The monastic office for Louis IX," 71-86.

73 See Gaposchkin, "Philip the Fair," 53-61; eadem, "Louis IX et la mémoire liturgique," 29-31.

74 See Gaposchkin, "Louis IX and Liturgical Memory," 269. 
Ludovicus decus regnantium we read: "In almost every text of the office, a Psalm verse was retooled in such a way as to make Louis conform to biblical prescription and to describe Louis in the language of the Psalms. In this way Louis was compared to David, who as author of the Psalms provided the model of the sacral and saintly king. (...)."

According to Gaposchkin "This technique for sacralizing Louis's royalty was initially established in the Dominican Nunc laudare, from which a number of texts were retooled for Ludovicus decus regnantium." 75 At the same time the Benedictine version of Lauda celestis regio (from the royal Abbeys of Saint-Denis and Saint-Germain-des-Prés) exhibits more interest in emphasising the royalty of the saintly king by evoking the figures of the Old Testament kings: Louis sat on the throne of David and did the justice of Solomon, ${ }^{76}$ and his sanctity is compared to David's humility, the mercifulness of Solomon and truthfullness of Ezechias:

Louis is made magnified

By miracle divine,

A David in humility,

With Solomon's serenity,

Ezechias's verity,

In the eyes of all mankind,

A Josiah in benignity,

For his people, a man of sanctity,

Honour's graces on him shine.

Magnificat. ${ }^{77}$

It is also worth noting that the Benedictine version of the office Lauda celestis mentions David as the royal figure much more frequently than its Cistercian and secular versions. ${ }^{78}$ Such a point of view is obviously reiterated and extended in Ludovicus decus regnantium (the office of Dominican origin, performed at the Sainte-Chapelle, which includes an antiphon to Benedictus), which admits that Louis was David's "twin in virtue," while the Responsory calls Saint Louis even more glorious in humility than David himself:

\footnotetext{
75 See ibidem, 270.

76 David regni sedit in solio, Salomonis utens iudicio. See Gaposchkin, "The monastic office for Louis IX," 73 .

77 See Gaposchkin, ibidem, 85. See also Ludovicus decus regnantium: antiphon on Magnificat at Second Vespers, in Gaposchkin, Blessed Louis, the Most Glorious of Kings, 201-202.

78 See Gaposchkin, Blessed Louis, the Most Glorious of Kings, 71-86 (appendix: Lauda celestis. A comparison of three versions).
} 
He appeared glorious,

not because of the adornment of a ruler,

but because he excelled unadorned,

in the manner of David playing;

and the authority of a ruler

was not lacking in him because of this. ${ }^{79}$

If in both Jacob of Lausanne's and John of Aragon's sermons Louis's sagacity makes him comparable to king Salomon, ${ }^{80}$ James of Viterbo, in his fifth sermon on Saint Louis (Thronus eius, 1308), affirms that "Louis excelled as a prince, as did David, through wisdom, which is knowledge of the divine." ${ }^{81}$ John of Aragon's reflections on Louis's similarity to David seem to be more varied. In addition to the description of French heavenly royal unction, making Louis IX the true successor of David as king and God's elected, two of John sermons (Rex qui sedet and Inveni David) are built on Psalm 88:21: "I have found David my servant, with my holy oil I have anointed him." In this way, John links the French monarch to king David "as illustrious in activity, exceptional in humility, burning with devotion, right in justice and equity, and pious in kindness." ${ }^{\prime 2}$ The antiphon on Benedictus in Ludovicus decus regnantium, followed by antiphons of Little Hours portrays Saint Louis as an actual David of his age:

Blessed be the Lord and give him praise, Who for all of us did raise

A horn he loved no less than David in his royal days,

A twin to him in virtue too,

Louis ruled in peace as kings should do.

Thus when his rule on earth was done

The goal of heaven Louis won

P. Benedictus: Blessed be the Lord God of Israel

79 Gloriosus apparuit, non cultu presidentis sed cum incultus prefuit, more David ludentis; nec ex hoc sibi defuit, auctoritas regentis, English translation after Gaposchkin, "Political Ideas in Liturgical Offices of Saint Louis," 67. See also eadem, "Louis IX and Liturgical Memory," 272.

8o $\quad$ For John of Aragon's sermon, Rex qui sedet, see Gaposchkin, "Talking about Kingship," 158-159; eadem, Blessed Louis, the Most Glorious of Kings, 162, 184. For Jacob's Rex sapiens, Videte regem Salomonem, see n. 70 .

81 See Gaposchkin, "Talking about Kingship," 157.

82 See ibidem, 16o. On David's figure in the sermons of Jacob of Lausanne, see Gaposchkin, The Making of Saint Louis, 120-123. 
Terce

Among many nations there was not a king like him, and he was beloved to his God, and God made him king over all Israel.

Sext

And in chains God left him not, till He brought him the sceptre of the kingdom, and power against those that oppressed him

None

And the Lord magnified him over all Israel: and gave him the glory of a kingdom, such as no king of Israel had before him. ${ }^{83}$

In Franciscan eyes, Cecilia Gaposchkin argues, humility is the most important trait of Saint Louis making him comparable to David. Other preachers or hagiographers abstain from making this comparison. Although they are far from neglecting humility as a truly royal virtue, they insist on a more royal model of his sanctity. ${ }^{84}$ Against this ideological background, Gerard of Saint-Quentin's image of Louis IX appears even more striking, for his account of the Translatio Sancte Corone, together with the Lives of the saintly king, Fuit in diebus nostris rex, remain the only known hagiographical writings representing Saint Louis becoming a second king David as the performer of the translation of the Passion relics. One cannot, however, forget that Gerard's account contrary to other texts discussed above evoking David as Saint Louis' biblical prefiguration - does not refer to the king's personal sanctity, but to the translation of the Crown of Thorns and the Holy Cross. Moreover, it was composed before the canonisation of Louis IX, and there is no evidence that its writing would be related to the latter in any way.

Lastly, the Psalter of Saint Louis ${ }^{85}$ should be mentioned. This masterpiece of thirteenth century illumination, decorated with 78 full-page miniatures presenting scenes from the Old Testament, beginning with the offering of Abel

83 Benedictus Dominus / qui nobis erexit / cornu, quod paulominus / a David dilexit; / hic virtute geminus, / rex in pace rexit, / quem regendi terminus / ad celos direxit. P. Benedictus. Ad Horas Minores. Ad Tertiam. In gentibus multis non erat rex similis ei et dilectus Deo suo erat et posuit Deus regem eum super Israel. Ad Sextam. In vinculis non dereliquit eum Dominus, donec afferret illi sceptrum regni et potentiam adversus eos qui eum deprimebant. Ad Nonam. Magnificavit eum Dominus super omnem Israel et dedit illi gloriam regni qualem nullus habuit ante eum rex. Cf. Luke 1:68-79; Ezekiel 13:26; Wisdom 10:14; 2 Chronicles 29:25. See Gaposchkin, Blessed Louis, the Most Glorious of Kings, 200 (Lat.), 201 (Eng.).

84 See Gaposchkin, "Talking about Kingship," 141-145; eadem, "Political Ideas in Liturgical Offices of Saint Louis," 68-69; eadem, Blessed Louis, the Most Glorious of Kings, 106-107, $116-117,123$.

85 See BnF, Ms. Latin 10525. Cf. Stahl, Picturing Kingship; Guest, "The People Demand a King." According to Patricia Stirnemann, Saint Louis would never enjoy the Psalter which 


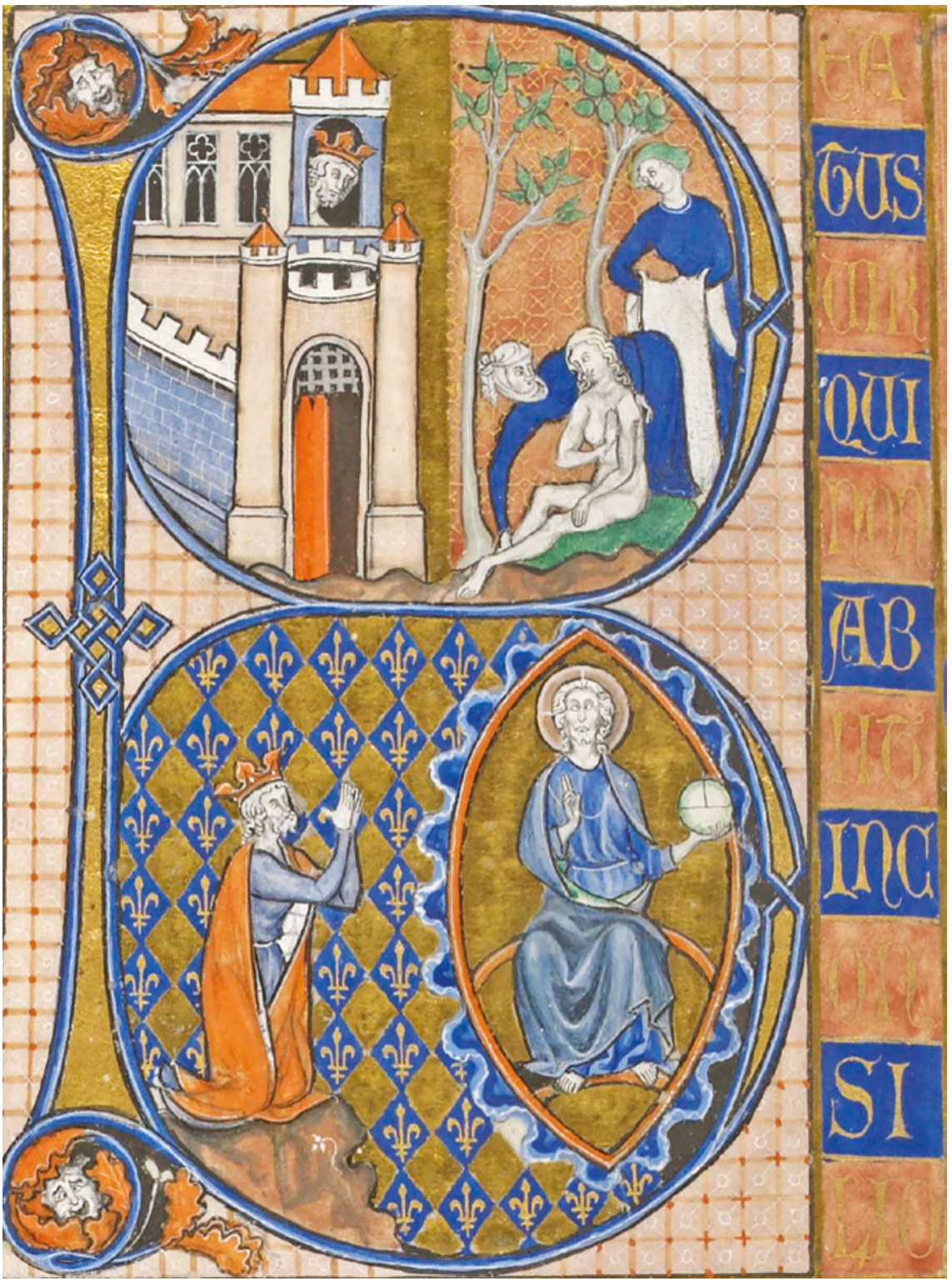

FIGURE 7.4 King David penitent, Psalter of Saint Louis, Paris, ca. 1270-1274, BnF, Ms. Latin 10525 , fol. $85 \mathrm{v}$ 
and Cain and ending with the first years of Saul's reign, also links the king of France to David. The initial series of miniatures is followed by the calendar and another miniature representing two scenes from David's life: the king watching Bathsheba take a bath, and subsequently kneeling before God as a contrite repentant. The latter scene is displayed on the blue background decorated with gold lily blossoms ${ }^{86}$ - another evidence that Saint Louis (or the kings of France generally) used to be identified with David. On the right bordure of the page first the words of Psalm 1 are inscribed: Beatus vir. This is the last miniature of the Psalter. It is worth noting that in contrast to David, Saul, portrayed on seven images, is not once represented on the fleurdelysé pattern.

\section{5}

\section{Conclusions}

The issue of the translation of Jerusalem, as well as of the Holy Land and the Chosen People to Paris ${ }^{87}$ and Gaul is well is evident in both the hagiographic narratives and liturgical sources. It echoes the Byzantine imperial ideology which originated during the period when the Jerusalem relics began to be transferred to Constantinople in Heraclius's reign. However, in the theological and political ideology of the Kingdom of France, it evolved independently and its origins should be sought in the Carolingian age. Comparing the translation of the relics to the introduction of the Ark of the Covenant to Jerusalem by David in general, and the translation of the Passion relics to Christ's entering Jerusalem in particular, is a stereotypical topos of the mediaeval hagiography and its use in the recounting of the translation of the Passion relics to Paris is a common feature of hagiographical writings rather than a special one.

The acts of translation - liturgical rituals of the transfer of relics to a new place of veneration - emulated the legendary finding of the Holy Cross by the mother of Constantine the Great, Saint Helena, and the deposition of its parts in imperial basilicas in Jerusalem, Constantinople and Rome. Another model to follow was the solemn introduction of the Holy Cross to Jerusalem by the emperor Heraclius, interpreted as a repetition of the entry of the Ark

would not be executed until 1274. See Thomas, and Stirnemann, Der Psalter Ludwigs des Heiligen, 37 .

86 See BnF, Ms. Latin 10525, fol. 85v. <https://gallica.bnf.fr/ark:/12148/btvib8447877n/fi84 .image>, accessed 26 January, 2021. Cf. Stahl, "Bathsheba and the Kings," 427-434.

87 On the foundation of the Sainte-Chapelle interpreted as a sign of the "translation of Jerusalem" to Paris, see Müller, "Paris, das neue Jerusalem?"; La Sainte-Chapelle de Paris. Royaume de France ou Jérusalem céleste?. See also Pysiak, The King and the Crown of Thorns, 397-429, 430-461. 
of the Covenant by David or of Christ's entry into Jerusalem. As I have tried to argue in this paper, this medieval topos also served the ambition of the late thirteenth and early fourteenth century chroniclers and hagiographers to fashion Saint Louis as a contemporary David, the pious and godly king of a New Israel - France. ${ }^{88}$

\section{Bibliography}

\section{Primary Manuscript Sources}

A drawing of Matthew Paris, Chronica majora, Corpus Christi College, Ms. 16.

Parisian lectionary: Fuit in diebus nostris in Francia rex christianissimus, Bibliothèque nationale de France (= BnF), Ms. Latin 11754, BHL 5050.

The Psalter of Saint Louis, Bibliothèque nationale de France (= BnF), Ms. Latin 10525. <https://gallica.bnf.fr/ark:/12148/btvib8447877n?rk=21459;2>, accessed 26 January 2021.

\section{Printed Sources}

Admonitio generalis, edited by Alfred Boretius. In Monumenta Germaniae Historica, Legum sectio II, Capitularia regum Francorum, vol. 1, no. 22, 53-62. Hannover: Hahn, 1883 .

Alcuini sive Albini Epistolae, edited by Ernst Dümmler. In Monumenta Germaniae Historica Epistolae, Karolini aevi, vol. 4/2. Berlin: Weidmann, 1895.

Annales Mettenses priores, edited by Bernhard von Simson. In Monumenta Germaniae Historica Scriptores rerum Germanicarum in usum scholarum separatism editi, vol. 10, Hannover - Leipzig: Hahn, 1905.

Beati Ludovici vita partim ad lectiones partim ad sacrum sermonem parata, edited by Natalis de Wailly, Léopold Delisle and Charles Jourdain (BnF, Ms Latin 11754). In Recueil des Historiens des Gaules et de la France [Rerum Francicarum et Gallicarum Scriptores, vol. 23], 167-176. Paris: H. Welter, 1894.

Beatus Ludovicus, edited by M. Cecilia Gaposchkin. In Blessed Louis, the Most Glorious of Kings: Texts Relating to the Cult of Saint Louis of France, translated with Phyllis B. Katz, 105-151. Notre Dame, IN: University of Notre Dame Press, 2012.

Épitaphier du vieux Paris, edited by Émile Raunié, 3 vols. Paris: Imprimerie Nationale, 1890-1901.

88 For a discussion of the ideological meaning of the royal insignia and coronation robes of the Capetian kings, designed at the beginning of the thirteenth century and very likely used for the anointment of Louis IX in 1226, see Pinoteau, "La tenue de sacre de Saint Louis IX." 
Exuviae Sacrae Constantinopolitanae, edited by Paul Edouard Didier Riant (vols. 1-2) and Fernand de Mély (vol. 3). Geneva: G. Fick, 1878-79 (vols. 1-2); Paris: Ernest Leroux, 1904 (vol. 3).

Gautier Cornut.De susceptione Coronae Domini, edited by Natalis de Wailly and Léopold Delisle. In Recueil des Historiens des Gaules et de la France. Rerum Francicarum et Gallicarum Scriptores, vol. 22, 26-32. Paris: Victor Palmé, 1865.

Gerard de Saint-Quentin. Translatio Sancte Corone Domini Ihesu Christi a Constantinopolitana urbe ad civitatem Parisiensem, facta anno Domini MCCXLI, regnante Ludovico, filio Ludovici Regis Francorum. In Fernand de Mély, Exuviae sacrae Constantinopolitanae, vol. 3: La Croix des premiers croisés. La Sainte Lance. La Sainte Couronne, 102-112. Paris: E. Leroux, 1904.

Guillaume de Saint-Pathus. Sermon en l'honneur de Saint Louis, edited by HenriFrançois Delaborde [Extrait de la "Bibliothèque de l'École des des chartes," vol. 63]. Nogent-le-Rotrou: Daupeley-Gouverneur, 1902.

Helgaud de Fleury. Vie de Robert le Pieux. Epitoma vitae regis Rotberti Pii, edited by Robert Henri Bautier et Gilette Labory [Sources d'histoire médiévale, vol. 1]. Paris: Centre National de la Recherche Scientifique, 1965.

Hericus Antissiodorensis monachus. Miracula sancti Germani Antissiodorensis episcopi, edited by Jacques-Paul Migne. In Patrologiae cursus completus. Series Latina, vol. 124, 1207-1270. Paris: Garnier frères, 1879.

Iacobus de Dinant. Excerpta e Tractatu de translatione beatae Genovefae virginis, edited by Natalis de Wailly, Léopold Delisle and Charles Jourdain. In Recueil des Historiens des Gaules et de la France. Rerum Francicarum et Gallicarum Scriptores, vol. 23, 139142. Paris: Victor Palmé, 1876.

Matthew Paris. Chronica majora, edited by Henry Richard Luard, vol. I-VII. In Rerum Brittanicarum Medii Aevi Scriptores or Chronicles and Memorials of Great Britain and Ireland during the Middle Ages [Rolls Series]. London - Oxford - Edinburgh Dublin: Longman and Co. - Trübner and Co. - Parker and Co. - Macmillan and Co. A \& C Black - A. Thom, 1872-1883.

Matthew Paris. [Historia minor], Historia Anglorum sive, ut vulgo dicitur, Historia minor, edited by Frederic Madden, vols. 1-3. In Rerum Brittanicarum Medii Aevi Scriptores or Chronicles and Memorials of Great Britain and Ireland during the Middle Ages [Rolls Series]. London: Longmans, Green, Reader and Dyer, 1866-1869.

Prologus Legis Salicae, edited by Karl August Eckhardt. In Monumenta Germaniae Historica. Legum Sectio I. Legum nationum Germanicarum, vol. 4/2, 3-9. Hannover: Hahn, 1969.

Rabanus Maurus. Homiliae, edited by Jacques-Paul Migne. In Patrologiae cursus completus. Series Latina, vol. 110. Paris: Garnier frères, 1864.

Reversio Sanctae Crucis [внL 4178], edited and translated into English by Stephan Borgehammar. In Stephan Borgehammar, "Heraclius Learns Humility," 180-191. 
The Sanctity of Louis IX. Early Lives of Saint Louis by Geoffrey of Beaulieu and William of Chartres, edited by M. Cecilia Gaposchkin and Sean L. Field. Translated to English by Larry F. Field. Ithaca - London: Cornell University Press, 2014.

\section{Secondary Literature}

Baert, Barbara. A Heritage of the Holy Wood. The Legend of the True Cross in Text and Image [Cultures, Beliefs and Traditions, vol. 22]. Leiden - Boston: Brill, 2004.

Bonnardot, Hippolyte. L'Abbaye royale de Saint-Antoine-des-Champs de l'ordre de Cîteaux. Paris: Librairie de Féchoz et Letouzey, 1881.

Borgehammar, Stephan. "Heraclius Learns Humility: Two Early Latin Accounts Composed for the Celebration of Exaltatio Crucis." Millennium. Jahrbuch zu Kultur und Geschichte des ersten Jahrtausends n. Chr. Yearbook on the Culture and History of the First Millennium C.E., 6 (2009), 145-201.

Borghi, Beatrice. In viaggio verso la Terrasanta. La basilica di Santo Stefano in Bologna. Bologna: Minerva Edizioni, 2010.

Borghi, Beatrice. "In viaggio verso la Terrasanta. La basilica di Santo Stefano in Bologna." In Come a Gerusalemme. Evocazioni, riproduzioni, imitazioni dei luoghi santi tra Medioevo ed età moderna, edited by Anna Benvenuti and Pierantonio Piatti [Toscana Sacra, vol. 4], 577-6o7. Florence: Sismel, 2013.

Bozóky, Édina. La politique des reliques de Constantin à Saint Louis. Protection collective et légitimation du pouvoir. Paris: Beauchesne, 2006.

Charansonnet, Alexis, and Morenzoni, Franco. "Prêcher sur les reliques de la Passion à l'époque de Saint Louis." In La Sainte-Chapelle de Paris. Royaume de France ou Jérusalem céleste? Actes du colloque (Paris, Collège de France, [6-8 décembre] 2001), edited by Christine Hediger, 61-99. Turnhout: Brepols, 2007.

Dagron, Gilbert. Constantinople imaginaire. Études sur le recueil des 'Patria'. Paris: Presses Universitaires de France, 1984.

Dagron, Gilbert. Empereur et prêtre. Étude sur le «césaropapisme» byzantin. Paris: Gallimard, 1996.

Dagron, Gilbert. Naissance d'une capitale. Constantinople et ses institutions de 330 à 451 [Collection Bibliothèque Byzantine, Études, vol. 7]. Paris: Presses Universitaires de France, 1974 .

Deshman, Robert. "The Exalted Servant. The Ruler Theology of the Prayerbook of Charles the Bald." Viator. Medieval and Renaissance Studies, 11 (1980), 385-417.

Diebold, William Joseph. "The Ruler Portrait of Charles the Bald in the S. Paolo Bible." The Art Bulletin, 76 no. 1 (1994), 6-18.

Durand, Jannic. "La translation des reliques impériales de Constantinople à Paris." In Le trésor de la Sainte-Chapelle, edited by Jannic Durand and Marie-Pierre Laffitte, 37-41. Paris: Réunion des Musées Nationaux, 2001.

Dutton, Paul Edward, and Kessler, Herbert Leon. The Poetry and Paintings of the First Bible of Charles the Bald. Ann Arbor: University of Michigan Press, 1997. 
Dźwigała, Bartłomiej. "Constantine, Helena and Heraclius in the Latin Kingdom of Jerusalem." In The Journal of Ecclesiastical History, 1(72) (2021), 18-35.

Ehlers, Joachim. "Politik und Heiligenverehrung in Frankreich." In Politik und Heiligenverehrung im Hochmittelalter, edited by Jürgen Petersohn [Vorträge und Forschungen, vol. 42], 149-175. Sigmaringen: Thorbecke, 1994.

Engberg, Sysse Gudrun. "Romanos Lekapenos and the Mandilion of Edessa." In Byzance et les reliques du Christ. Actes de la table ronde Les reliques de la Passion, tenue à Paris, à l'occasion du XX $X^{e}$ Congrès International des Études byzantines 19-25 août 2001, edited by Jannic Durand and Bernard Flusin [Monographies, vol. 17], 123-142. Paris: Centre de recherche d'histoire et civilisation de Byzance, 2004.

Epstein, Marcy J. “Ludovicus Decus Regnantium: Perspectives on the Rhymed Office.” Speculum, 53 no. 2 (1978), 283-334.

Flusin, Bernard. "Construire une nouvelle Jérusalem: Constantinople et les reliques." In L'Orient dans l'histoire religieuse de l'Europe. L'invention des origines, edited by Mohammad Amir Moezzi and John Scheid [Bibliothèque de l'École pratique des Hautes Études, Section des Sciences religieuses, vol. 110], 51-70. Turnhout: Brepols, 2000.

Flusin, Bernard. "Les reliques de la Sainte-Chapelle et leur passé impérial à Constantinople." In Le trésor de la Sainte-Chapelle, edited by Jannic Durand and Marie-Pierre Laffitte, 20-33. Paris: Réunion des Musées Nationaux, 2001.

Folz, Robert. Le Couronnement impérial de Charlemagne. Paris: Gallimard, 1964.

Frolow, Anatole. "La relique de la Vraie Croix." Archives de l'Orient chrétien, 8 (1965), 76-92.

Frolow, Anatole. "La Vraie Croix et les expéditions d'Héraclius en Perse." Revue des Études Byzantines, 11 (1953), 88-105.

Gabriele, Matthew. An Empire of Memory. The Legend of Charlemagne, the Franks, and Jerusalem before the First Crusade. Oxford: Oxford University Press, 2011.

Gaposchkin, M. Cecilia. "Between Historical Narration and Liturgical Celebrations: Gautier Cornut and the Reception of the Crown of Thorns in France." Revue Mabillon, n.s. 30 [= 91] (2019), 91-145.

Gaposchkin, M. Cecilia. Blessed Louis, the Most Glorious of Kings: Texts Relating to the Cult of Saint Louis of France, translated with Phyllis B. Katz. Notre Dame, IN: University of Notre Dame Press, 2012.

Gaposchkin, M. Cecilia. "Louis IX and Liturgical Memory." In Memory and Commemoration in Medieval Culture, edited by Elma Brenner, Meredith Cohen and Mary Franklin-Brown, 261-278. Aldershot: Ashgate Publishing, 2013.

Gaposchkin, M. Cecilia. "Louis IX et la mémoire liturgique." Revue d'histoire de l'église de France, 95 (2009), 23-34.

Gaposchkin, M. Cecilia. "Ludovicus Decus Regnantium: the Liturgical Office for Saint Louis and the Ideological Program of Philip the Fair." Majestas, 10 (2003), 27-9o. 
Gaposchkin, M. Cecilia. The Making of Saint Louis. Kingship, Sanctity, and Crusade in the Later Middle Ages. Ithaca - London: Cornell University Press, 2008.

Gaposchkin, M. Cecilia. "The monastic office for Louis IX of France: Lauda Celestis Regio." Revue Mabillon, n.s., 20 [= 81] (2009), 55-86.

Gaposchkin, M. Cecilia. "Philip the Fair, the Dominicans, and the liturgical Office for Louis IX: New perspectives on Ludovicus Decus Regnantium." Plainsong and Medieval Music, 13 no. 1 (2004), 33-61.

Gaposchkin, M. Cecilia. "Political Ideas in Liturgical Offices of Saint Louis." In Political Plainchant?: Music, Text and Historical Context of Medieval Saints' Offices, edited by Roman Hankeln [Wissenschaftliche Abhandlungen, vol. 91], 59-8o. Ottawa: Institute of Mediaeval Music, 20o9.

Gaposchkin, M. Cecilia. "Talking about Kingship when Preaching about Saint Louis.” In Preaching and Political Society: from Late Antiquity to the End of the Middle Ages/ Depuis l'Antiquité tardive jusqu'à la fin du Moyen Âge, edited by Franco Morenzoni [Studies on Patristic, Medieval, and Reformation Sermons and Preaching, vol. 10], 135-172. Turnhout: Brepols, 2013.

Garipzanov, Ildar H. The Symbolic Language of Royal Authority in the Carolingian World (c.751-877) [Brill's Series on the Early Middle Ages, vol. 16]. Leiden: Brill, 2008.

Garrisson, Mary. "The Franks as the New Israel? Education for an Identity from Pippin to Charlemagne." In The Uses of the Past in the Early Middle Ages, edited by Yitzak Hen and Matthew Innes, 114-161. Cambridge: Cambridge University Press, 2000.

Graboïs, Aryeh. "Un mythe fondamental de l'histoire de France au Moyen Âge: Le « roi David » précurseur du « roi très chrétien »." Revue Historique, 287 no. 1 (1992), 11-31.

Guest, Gerald B. "The People Demand a King: Visualizing Monarchy in the Psalter of Louis IX." Studies in Iconography, 23 (2002), 1-27.

Hahn, Cynthia. Strange Beauty (Issues in the Making and Meaning of Reliquaries, 400circa 1204). University Park: Penn State University Press, 2012.

Kantorowicz, Ernst Hartwig. Laudes Regiae. A Study in Liturgical Acclamations and Medieval Ruler Worship. Berkeley - Los Angeles: University of California Press, 1946.

Klein, Holger A. "Constantine, Helena, and the Cult of the True Cross in Constantinople." In Byzance et les reliques du Christ, edited by Jannic Durand and Bernard Flusin [Centre de Recherche d'histoire et civilisation byzantine. Monographies, vol. 17], 31-59. Paris: Association des amis du Centre d'histoire et civilisation de Byzance, 2004.

Klein, Holger A. "Sacred Relics and Imperial Ceremonies at the Great Palace of Constantinople." In Visualisierungen von Herrschaft. Frühmittelalterliche Residenzen Gestalt und Zeremoniell, Internationales Kolloquium, 3./4. Juni 2004 in Istanbul, edited by Franz Alto Bauer [Byzas, vol. 5], 79-99. Istanbul: Ege Yayınları, 2006. 
La Sainte-Chapelle de Paris. Royaume de France ou Jérusalem céleste? Actes du colloque (Paris, Collège de France, [6-8 décembre] 2001), edited by Christine Hediger. Turnhout: Brepols, 2007.

Le Goff, Jacques. Saint Louis. Paris: Gallimard, 1996.

Manikowska, Halina. Jerusalem - Rome - Compostela. Peregrinationes Majores at the End of the Middle Ages [in Polish]. Wroclaw: Wroclaw University Press, 2008.

Manikowska, Halina. "Translation of Jerusalem to Wroclaw." In Church - Culture Society. Studies in Medieval and Modern History, edited by Stanisław Bylina, Ryszard Kiersnowski, Stefan K. Kuczyński, Henryk Samsonowicz, Józef Szymański and Hanna Zaremska, 63-75 [in Polish]. Warsaw: Semper, 2000.

Mergiali-Sahas, Sophia. "Byzantine Emperors and Holy Relics. Use and Misuse of Sanctity and Authority." Jahrbuch der Österreichischen Byzantinistik, 51 (2001), 41-6o.

Michałowski, Roman. "Religious Foundations of the Monarchy in the Early Middle Ages" [in Polish]. Kwartalnik Historyczny, 105, no. 4 (1998), 1-32.

Michałowski, Roman. "The Problem of Language in the Western European Ideology of Royal Power." In Economy, People, Power. Studies Offered to Juliusz Łukasiewicz on the Occasion of his 75th Birthday, edited by Michał Kopczyński and Antoni Mączak, 39-48 [in Polish]. Warsaw: Krupski i S-ka, 1998.

Michałowski, Roman. The Gniezno Summit. The Religious Premises of the Founding of the Archbishopric of Gniezno [East Central and Eastern Europe in the Middle Ages, 450-1450, vol. 38]. Leiden - Boston: Brill, 2016.

Müller, Matthias. "Paris, das neue Jerusalem? Die Ste-Chapelle als Imitation der Golgatha-Kapellen." Zeitschrift für Kunstgeschichte, 69 (1996), 325-336.

O'Brien, Conor. "Chosen Peoples and New Israels in the Early Medieval West." Speculum, 95, no. 4 (2020), 987-10o9.

Orselli, Alba Maria. "Simboli della città cristiana fra tardoantico e medioevo." In $L a$ città e il sacro, edited by Franco Cardini, 419-45o. Milano: Credito Italiano, 1994.

Ousterhout, Robert G. “The Church of Santo Stefano: A 'Jerusalem' in Bologna." Gesta, 2o, no. 2 (1981), 311-321.

Ousterhout, Robert G. "Santo Stefano e Gerusalemme." In Stefaniana. Contributi per la storia del complesso di S. Stefano in Bologna, edited by Gina Fasoli [Documenti e studi Deputazione di Storia Patria per le Province di Romagna, vol. 17], 131-158. Bologna: Presso la Deputazione di Storia Patria, 1985.

Patlagean, Évelyne. "L'entrée de la sainte Face d'Edesse à Constantinople en 944." In La religion civique à l'époque médiévale et moderne (chrétienté et islam), edited by André Vauchez [Collection de École Française de Rome, vol. 13], 21-35. Rome: École Française de Rome, 1995.

Petersohn, Jürgen. “Kaisertum und Kultakt in der Stauferzeit." In Politik und Heiligenverehrung im Hochmittelalter, edited by Jürgen Petersohn [Vorträge und Forschungen, vol. 42], 101-146. Sigmaringen: Thorbecke, 1994. 
Petersohn, Jürgen. "Saint Denis-Westminster-Aachen. Die Karlstranslation von 1165 und ihre Vorbilder." Deutsches Archiv für Erforschung des Mittelalters, 31 (1975), $420-454$.

Pinoteau, Hervé. "La tenue de sacre de Saint Louis IX roi de France. Son arrière-plan symbolique et la «renovatio regni Juda »." In Vingt-cinq ans d'études dynastiques, edited by Hervé Pinoteau, 447-504. Paris: Éditions Christian, 1982; first published in Itinéraires, 162 (1972), 120-166.

Pysiak, Jerzy. "The Cult of Passion Relics in the Ideology of Royal Power in France and England in the 13th Century: Saint Louis and Henry III." In Sacrum. Image and Function in Medieval Society, edited by Aneta Pieniądz-Skrzypczak, Jerzy Pysiak [Aquila Volans, vol. 1], 290-303 [in Polish]. Warsaw: Warsaw University Press, 2005. Pysiak, Jerzy. The King and the Crown of Thorns: Kingship and the Cult of Relics in Capetian France. Bruxelles - New York - Oxford - Warsaw - Wien: Peter Lang, 2020. Pysiak, Jerzy. The King and the Crown of Thorns. The Cult of Relics in Capetian France [Aquila Volans, vol. 2] [in Polish]. Warsaw: Warsaw University Press, 2012.

Pysiak, Jerzy. "Saint Louis: A Hagiographic Portrait of an Ideal Ruler" [in Polish]. Kwartalnik Historyczny, 103, no. 4 (1996), 57-86.

Raunié, Émile. "Abbaye royale de Saint-Antoine-des-Champs." In Épitaphier du vieux Paris, vol. 1, 127-145. Paris: Imprimerie Nationale, 1890.

Schutz, Herbert. The Carolingians in Central Europe, Their History, Arts and Architecture: A Cultural History of Central Europe, 750-90o [Cultures, Beliefs, and Traditions, vol. 18]. Leiden: Brill, 2003.

Sommerlechner, Andrea. "Kaiser Herakleios und die Rückkehr des heiligen Kreuzes nach Jerusalem. Überlegungen zu Stoff-und Motivgeschichte." Römische Historische Mitteilungen, 45 (2003), 319-36o.

Sorbelli, Albano. "La 'Santa Jerusalem' Stefaniana." L'Archiginnasio. Bollettino della Biblioteca Comunale di Bologna, 35 (1940), 14-28.

Stahl, Harvey. "Bathsheba and the Kings: The Beatus Initial in the Psalter of Saint-Louis (Paris, BNF, ms lat. 10525)." In The Illuminated Psalter. Studies in the Content, Purpose and Placement of its Images, edited by Frank O. Büttner, 427-434. Turnhout: Brepols, 2001.

Stahl, Harvey. Picturing Kingship. History and Painting in the Psalter of Saint Louis. University Park: Pennsylvania State University Press, 2008.

Steger, Hugo. David rex et propheta. König David als vorbildliche Verkörperung des Herrschers und Dichters im Mittelalter, nach Bilddarstellungen des achten bis zwölften Jahrhunderts [Erlanger Beiträge zur Sprach- und Kunstwissenschaft, vol. 6]. Nürnberg: Verlag Hans Carl, 1961.

Strayer, Joseph Reese. "The Holy Land, the Chosen People, and the Most Christian King." In Action and Conviction in Early Modern Europe. Essays in Memory of E.H. Harbison, 
edited by Theodore K. Rabb and Jerrold E. Seigel. Princeton: Princeton University Press, 1969, 3-16; reedited in Medieval Statecraft and the Perspectives of History. Essays by Joseph R. Strayer, edited by John F. Benton and Thomas N. Bisson, 300-314. Princeton: Princeton University Press, 1971.

Szollosi, Vanessa. Les moniales de Saint-Antoine-des-Champs au XIII e siècle, Ph.D. dissertation submitted at the École Nationale des Chartes, 2007.

Thomas, Marcel, and Stirnemann, Patricia. Der Psalter Ludwigs des Heiligen: MS lat. 10525 der Bibliothèque nationale de France [Glanzlichter der Buchkunst, vol. 20]. Graz: Akademische Druck- und Verlagsanstalt, 2011.

Vincent, Nicholas. The Holy Blood. King Henry III and the Westminster Blood Relic. Cambridge: Cambridge University Press, 2001.

Weitzmann, Kurt. "The Mandylion and Constantine Porphyrogenitus." Cahiers archéologiques, 11 (1960), 163-184. 